\title{
OPTIMASI PULPING MENGGUNAKAN PROSES ALCELL DARI ALANG- ALANG PADA PEMBUATAN SELULOSA MIKROKRISTAL DENGAN ALAT BANTU MAE (Microwave Assisted Extraction)
}

\author{
Titis Puspitasari*, Indah Hartati, Harianingsih \\ Jurusan Teknik Kimia, Fakultas Teknik, Universitas Wahid Hasyim Semarang \\ Jl. Menoreh Tengah X/22, Sampangan, Semarang 5023 \\ *Email: titispuspitasari83@gmail.com
}

\begin{abstract}
Abstrak
Selulosa mikrokristal sebagai bahan pengisi tablet di indonesia masih dipenuhi dengan impor dari luar negeri dengan harga yang sangat mahal. Di Indonesia, salah satu bahan berkadar selulosa tinggi yang belum dimanfaatkan secara maksimal ialah alang-alang, dimana kandungan selulosa mencapai 42\%. Pada penelitian ini, dilakukan proses pulping alcell (campuran alkohol dan NaOH) berbantu MAE (Microwave Assisted Extraction) pada pulp alang-alang. Pulp alang-alang yang didapatkan selanjutnya dilakukan analisa bilangan kappa, alfaselulosa, dan uji FTIR. Variabel tetap ialah konsentrasi $\mathrm{NaOH} 1 \%$, sedangkan variabel berubah yang diteliti adalah konsentrasi etanol $(17,5 ; 20 ; 22,5 ; 25$; dan $27,5 \%)$, rasio berat volume $(1: 10 ; 1: 20,1: 30 ; 1: 40$; 1:50), waktu pemasakan (15; 30; 45; 60; 75 menit), daya pada ekstraktor (10; 30; 70; dan 100\% dari daya maksimum yakni 399 watt). Dari variabel tersebut didapatkan kondisi optimum konsentarsi etanol 27,5\%, rasio berat volume 1:10, waktu pemasakan 60 menit, dan daya pemasakan dengan menggunakan alat bantu MAE pada daya $50 \%$ dari daya maksimum 399watt. Hasil uji kadar alfa selulosa sebesar 84,4\% dan uji bilangan kappa sebesar 4,5\% dengan berat pulp 8,05 gram. Hasil analisa FTIR menunjukan adanya gugus fungsi.
\end{abstract}

\section{Kata Kunci: Alang-alang, Bilangan Kappa., Proses Alcell}

\section{PENDAHULUAN}

Selulosa mikrokristal merupakan senyawa murni yang sebagian terdepolimerisasi, berwarna putih, tidak berbau, tidak berasa, berbentuk bubuk kristal yang terdiri dari partikel berpori (Rowe, 2009). Selulosa mikrokristal banyak digunakan sebagai bahan pengikat, pengisi, penghancur dan pelicin pada proses pembuatan tablet (Rozzaq, 2013). Penggunaan selulosa mikrokristal sebagai bahan pengisi tablet di indonesia sendiri masih dipenuhi dengan impor dari luar negeri dan harganya yang mahal.

Proses pembuatan selulosa mikrokristal ini diantaranya melaui tahapan pulping, bleacing, dan hidrolisa. Pada proses pulping ada beberapa metode diantaranya yaitu mekanis, semi kimia, dan kimia. Dari beberapa metode tersebut yang umum digunakan ialah proses kimia, yaitu proses soda, sulfat (kraft), sulfit, dan organosolv. Proses organosolv adalah proses pemisahan serat dengan menggunakan bahan kimia organik seperti misalnya metanol, etanol, aseton, asam asetat, dan lain-lain. Proses ini telah terbukti memberikan dampak yang baik bagi lingkungan. Hal ini karena proses organosolv memberikan beberapa keuntungan, antara lain yaitu rendemen pulp yang dihasilkan tinggi, daur ulang limbah yang dihasilkan dapat dilakukan dengan mudah, tidak menggunakan unsur sulfur sehingga lebih aman terhadap lingkungan.

Organosolv juga merupakan proses pulping yang menggunakan bahan yang lebih mudah didegradasi seperti pelarut organik. Beberapa proses organosolv yang berkembang pesat pada saat ini, yaitu proses acetocell (pemasak berupa asam asetat) dan proses alcell (alcohol cellulose) dengan bahan kimia pemasak yang berupa campuran alkohol dan $\mathrm{NaOH}$. Proses tersebut telah memasuki tahap pabrik percontohan di beberapa negara misalnya di Kanada dan Amerika Serikat, sedangkan teknologi alcell di New Brunswick (Kanada) terbukti menghasilkan pulp dari bagase kayu yang setara dengan pulp kraft, rendemen cukup tinggi, sifat pendauran bahan kimia yang baik, harga terjangkau serta ramah lingkungan. 
Di indonesia sumber selulosa sangat banyak, seperti daun-daunan, rami, ampas tebu, eceng gondok, bonggol jagung, dan ganyong (Sanjana,2014). Salah satu bahan berkadar selulosa tinggi yang belum dimanfaatkan secara maksimal ialah alang-alang, dimana kandungan alfa selulosa mencapai 40,22\% (Kartikasari,2013). Menurut Natural Research Institute, International Rubber Research Institute, dan International Centre for Research in Agroforestry, 1996 dalam Miningsih 2016, alang-alang merupakan rumput tahunan yang memerlukan nutrisi yang rendah untuk dapat tumbuh dengan baik. Data BPS Kehutanan Indonesia tahun 2012 menyebutkan bahwa luas lahan kritis yang biasanya didominasi oleh alangalang adalah sebesar 27,295 juta hektar. Selain itu biomassa merupakan bahan yang bersifat biodegradabel sehingga ramah lingkungan.

Menimbang dari segi potensi sumber selulosa yang melimpah di Indonesia dan pengembangan teknologi pulping alcell yang memiliki banyak keuntungan, maka perlu diadakan pengkajian tentang proses pulping alang-alang pada pembuatan selulosa mikrokristal dengan menggunakan proses alcell.

\section{METODE PENELITIAN}

\section{Bahan penelitian}

Bahan-bahan yang digunakan dalam penelitian ini adalah alang-alang, aquades, natrium thiosulfate $\left(\mathrm{Na}_{2} \mathrm{~S}_{2} \mathrm{O}_{3}\right)$, asam asetat $\left(\mathrm{CH}_{3} \mathrm{COOH}\right)$, kalium iodida $(\mathrm{KI})$, kalium permanganat $\left(\mathrm{KMnO}_{4}\right)$, asam sulfat $\left(\mathrm{H}_{2} \mathrm{SO}_{4}\right)$, hidrogen peroksida $\left(\mathrm{H}_{2} \mathrm{O}_{2}\right)$, indikator ferroin, indikator amilum, ferro ammonium sulfat, potassium dikromat $\left(\mathrm{K}_{2} \mathrm{Cr}_{2} \mathrm{O}_{7}\right)$, dan natrium hidroksida $(\mathrm{NaOH})$.

\section{Peralatan}

Alat yang digunakan dalam penelitian ini meliputi MAE (Microwave Assisted Extraction), blender, screeninng 100 mesh, magnetic stirrer, gunting, toples, gelas beaker $2000 \mathrm{ml}$, pot $10 \mathrm{gr}$, pot 50 gr, masker, sarung tangan, kertas saring, erenmeyer $500 \mathrm{ml}$, labu ukur, labu alas bulat $1000 \mathrm{ml}$, gelas ukur, corong, pipet, buret, statif, dan pengaduk.

\section{Prosedur Penelitian}

Pembuatan Simplisia

Bahan baku berupa alang-alang yang terlebih dahulu dicuci dengan air dan di keringkan di bawah sinar matahari untuk 26 menghilangkan kandungan airnya lalu dipotong-potong kurang lebih $10 \mathrm{~cm}$. Setelah kering ampas tebu di blender sampai halus. Kemudian di screening 100 mesh, jadilah simplisia

\section{Pulping}

Timbang simplisia sebanyak 10 gram, masukan kedalam labu MAE $1000 \mathrm{ml}$, lalu buat larutan etanol konsentrasi 5\% rasio 1:20, tuang larutan etanol kedalam labu yang berisi simplisia, kemudian masukan dalam microwave dengan waktu 15 menit dan daya $10 \%$. Setelah itu saring pulp, dan keringkan.

\section{Uji Bilangan Kappa}

Pengujian bilangan kappa sesuai dengan prosedur pada SNI: 0494:2008.

\section{Uji Alfa, Gamma, dan Beta Selulosa}

Pengujian alfa, gamma, dan beta selulosa sesuai dengan prosedur pada SNI: 0444:2009.

\section{Analisa Gugus Fungsi}

Analisa gugus fungsi dulakukan dengan pengujian FTIR (Fourier Tramsform Infra Red)

\section{HASIL DAN PEMBAHASAN}

\section{Pengaruh konsentrasi etanol pada bilangan} kappa pulp alang alang

Variasi konsentrasi pelarut optimum ini dilakukan dengan beberapa variabel yakni 17,5; $20 ; 22,5 ; 25$; dan 27, 5\% etanol. Pada penelitian ini hasil optimum diperoleh pada ekstraksi dengan konsentrasi pelarut 27,5 \% etanol. Pengaruh konsentrasi terhadap hasil yield disajikan pada gambar 1 .

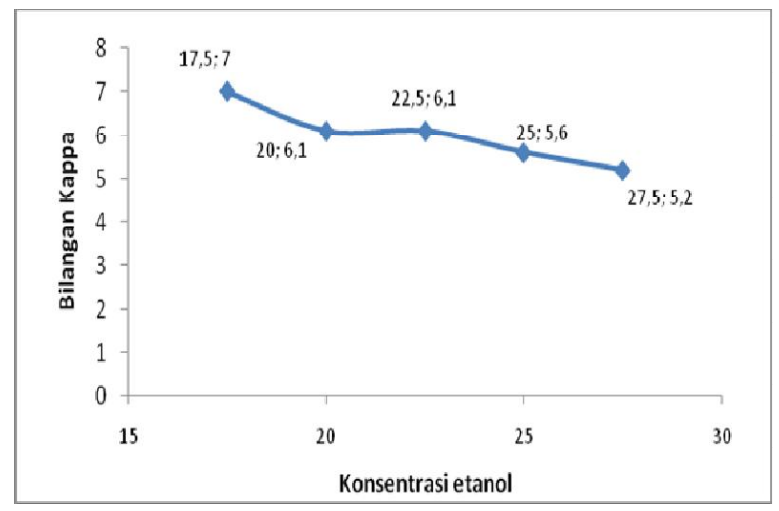

\section{Gambar 1. konsentrasi etanol vs bilangan kappa}

Gambar 1 menunjukan bahwa semakin tinggi konsentrasi etanol yang digunakan pada 
proses pulping alang-alang maka bilangan kappa akan semakin rendah. Bilangan kappa yang rendah menunnjukan lignin yang terekstrak banyak,. Penurunan tersebut karena lignin sebagai pengikat selulosa akan terpisah oleh pelarut etanol yang digunakan pada proses pulping. Menurut Coniwanti, 2009 dalam penelitian yang serupa dengan bahan baku enceng gondok menyatakan bahwa semakin tinggi konsentrasi etanol maka kadar lignin yang terambil akan semakin besar. Sesuai pada hasil penelitian ini yakni didapatkan kadar bilangan kappa yang lebih rendah pada konsentrasi etanol yang tinggi, yang menunjukan bahwa lignin yang terambil pada proses ekstraksi semakin banyak. Namun karena untuk mengantisipasi akan penggunaan konsentrasi etanol yang dapat mempengaruhi pembengkakan biaya pada proses serta memperhitungkan dampak yang akan ditimbulkan dilingkungan, maka untuk variabel konsentrasi kita membatasinya sampai pada konsentrasi $27,5 \%$.

\section{Pengaruh rasio solid liquid pada bilangan kappa pulp alang alang}

Guna mengetahui rasio optimum, ekstraksi dilakukan dengan perbandingan berat simplisia dengan volume pelarut antara 1:10 sampai 1:50. Umumnya dalam teknik ekstraksi konvensional, rasio bahan baku pelarut yang lebih besar akan meningkatkan perolehan hasil ekstrak. Namun, ekstraksi menggunakan gelombang mikro pada rasio yang lebih besar dapat mengakibatkan turunnya hasil ekstrak (Mandall dkk., 2007). Pengaruh rasio terhadap yield yang diperoleh dalam proses ekstraksi disajikan pada gambar 2 .

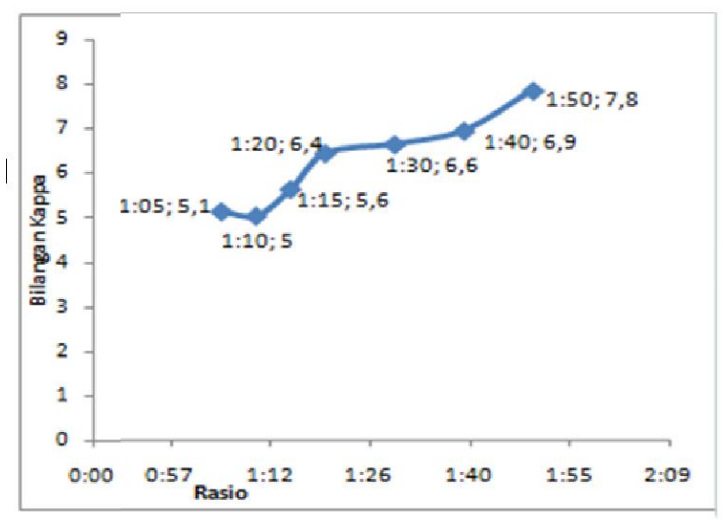

Gambar 2. rasio vs bilangan kappa
Hasil gambar 2 menunjukan bahwa semakin besar rasio yang digunakan akan menaikan bilangan kappa pada pulp. Kenaikan bilangan kappa disebabkan oleh pelarut air yang berlebih. Biasanya proses ekstraksi harus cukup volume pelarut untuk merendam bahan secara menyeluruh. Sedangkan aturan penggunaan parameter kelarutan dalam pemilihan pelarut antara molekul pelarut dan solut harus memiliki kekuatan gaya antar molekul yang mirip, untuk melarutkan solut tersebut (Hartati, 2010). Pada proses ekstraksi ini menggunakan etanol dan air sebagai pelarut, dengan nilai kelarutan 11 untuk lignin, air sebesar 23,4 dan etanol 12,7 (Gautam, 2016). Jika dilihat dari nilai kelarutan, lignin dengan air terentang sangat jauh, hal ini menyebabkan lignin dengan air akan cenderung sulit untuk larut, sehingga lignin yang terekstrak sedikit. Pada penelitian ini didapatkan bahwa semakin besar rasio solid liquid, bilangan kappa semakin tinggi yang menandakan ekstrak lignin sedikit. Jadi, rasio terbaik pada penelitian ini adalah 1:10 (g/v) dengan bilangan kappa sebesar $5 \%$.

\section{Pengaruh Daya pada bilangan kappa dengan alat bantu MAE (Microwave Assisted Extraction) \\ Daya pada alat akan memberikan panas} saat proses pulping berlangsung. Pada penelitian ini pulp yang dimasak pada daya $10,30,50,70$ dan $100 \%$ dari daya maksimum alat sebesar 399 watt.

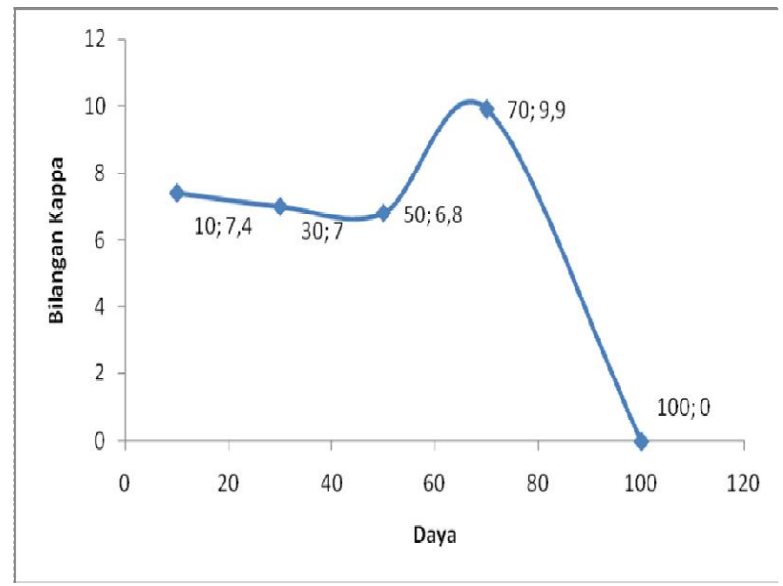

Gambar 3. Daya vs bilangan kappa 
Pada gambar 3 menunjukan semakin besar daya yang digunakan pada proses pulping dengan menggunakan larutan alcell menghasilkan bilangan kappa yang sedikit, dengan demikian lignin yang tersisa juga semakin sedikit. Pada daya $50 \%$ proses pulping telah mencapai kondisi optimum sehingga jika daya dinaikan lagi, akan terjadi penurunan hasil ekstrak. Pada daya 70\% terjadi kenaikan bilangan kappa, dimana lignin yang terekstrak menurun karena telah mencapai batasan kondisi optimum. Menurut Kholisoh (2016) kenaikan kadar lignin dikarenakan proses telah mengalami kondisi jenuh saat daya dinaikan hingga $70 \%$ dari alat pada pulping ampas tebu. Namun saat daya $100 \%$ dari alat menunjukan adanya kerusakan pada bahan yang akan dipulping yakni terlihat hitam dan berbau terbakar hingga muncul kerak pada labu MAE (Microwave Assisted Extraction) hal ini dikarenakan terjadi degradasi termal senyawa target. Karena keterbatasan alat dan kerusakan bahan pada proses, maka pemasakan tidak memungkinkan untuk dilanjutkan. Pada penelitian ini didapatkan daya terbaik pada $50 \%$ daya dari alat bantu MAE (Microwave Assisted Extraction) dengan penurunan kadar bilangan kappa mencapai $6,8 \%$.

\section{Pengaruh Waktu terhadap Bilangan Kappa}

Pengaruh waktu pada proses pulping alang-alang terhadap bilangan kappa menunjukan bahwa semakin lama waktu pemasakan pulp menyebabkan penurunan bilangan kappa, artinya kadar lignin yang dapat terambil meningkat.

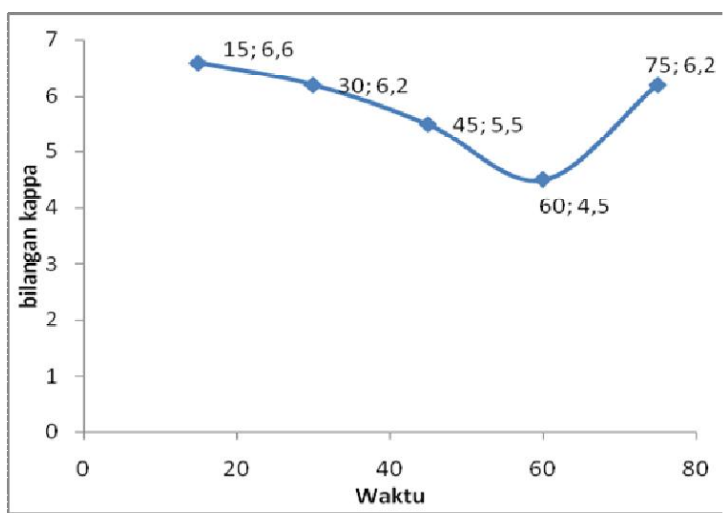

Gambar 4. waktu vs bilangan kappa

Pada gambar 4. pengaruh waktu terhadap bilangan kappa pada variabel $15 ; 30 ; 45 ; 60$; dan
75 menit. Pada menit 15 hingga menit ke 60 bilangan kappa mengalami penurunan, yang menunjukan lignin yang terambil banyak. Namun pada saat waktu dinaikan 75 menit terjadi kenaikan bilangan kappa yang menunjukan lignin yang terambil sedikit. Hal ini dikarenakan lignin yang akan diambil telah mencapai batas waktu optimum, sehingga saat waktu pemasakan di tambah kemungkinan lignin yang terambil akan berkurang. Waktu pemasakan yang lebih lama dapat menghambat reaksi delignifikasi, sehingga kadar lignin yang terambil mengalami penurunan (Lamtiar,2015). Jadi, waktu terbaik pada penelitian ini adalah waktu 60 menit dengan bilangan kappa sebesar 4,5\%.

\section{Kondisi Terbaik penelitian}

Kondisi pemasakan yang baik pada penelitian ini adalah konsentarsi etanol 27,5\%, rasio berat volume 1:10, waktu pemasakan 60 menit, dan daya pemasakan dengan menggunakan alat bantu MAE pada daya $50 \%$ dari daya maksimum 399watt. Bilangan kappa yang diperoleh dengan kondisi terbaik adalah $4,5 \%$ dengan berat pulp 8,05 gram. Sedangkan hasil penelitian (Wibisono ,2011) dalam pembuatan pulp dari alang-alang menggunakan proses konvensional mendapat hasil terbaik pada konsentrasi asam asetat yang digunakan $90 \%$, pada suhu proses pemasakan $100^{\circ} \mathrm{C}$ pada waktu 150 menit, dengan bilangan kappa sebesar 20,41 dan sebelum treatment sebesar 23,66, terjadi penurunan 3,25

\section{Analisa kandungan Alfa Selulosa}

Kadar Alfa selulosa digunakan sebagai parameter banyaknya selulosa yang terkandung dalam pulp. Kandungan Alfa selulosa pada pulp mempengaruhi kualitas terhadap pulp. Jika kandungan Alfa selulosa yang tinggi maka kualitas pulp akan semakin baik. Seperti yang terlihat pada tabel 1 .

Tabel.1 Kandungan Alfa Selulosa

\begin{tabular}{ccccc}
\hline No & $\begin{array}{c}\text { Alang- } \\
\text { alang }\end{array}$ & $\begin{array}{c}\text { Alfa\% } \\
\text { ) }\end{array}$ & $\begin{array}{c}\text { Beta( } \\
\%)\end{array}$ & $\begin{array}{c}\text { Gama( } \\
\%)\end{array}$ \\
\hline 1 & Awal & 78,08 & 3,73 & 11,87 \\
2 & Optimum & 84,4 & 13,5 & 8,5 \\
\hline
\end{tabular}

Pada penelitian ini menghasilkan kandungan alfa selulosa yang tinggi yakni 
84,4\%. Dari hasil ini bisa ditarik kesimpulan bahwa alang-alang bisa dijadikan sebagai bahan baku untuk membuat selulosa mikrokristal dengan proses pemasakan Organosolv (proses alcell) menggunakan campuran Etanol-NaOH dengan bantuan alat MAE (Microwave Assisted Extraction).

\section{Hasil analisa FTIR (Fourier Tramsform Infra Red)}

Spektroskopi FTIR (Fourier Tramsform Infra Red) merupakan salah satu teknik yang dapat mengidentifikasi serapan-serapan khas untuk masing-masing gugus fungsi yang terkandung dalam sampel. Pada penelitian ini akan mengidentifikasi serapan untuk selulosa yang memiliki gugus fungsional $\left(\mathrm{C}_{6} \mathrm{H}_{10} \mathrm{O}_{5}\right) \mathrm{n}$. Gugus fungsi selulosa biasanya ditunjukan dengan adanya gugus fungsi $\mathrm{O}-\mathrm{H}, \mathrm{C}-\mathrm{H}$, dan $\mathrm{C}-\mathrm{O}$ (Mutia,2014). Menurut Principle of instrumental analysis, Skoog, Holler, Nieman, 1998 gugus fungsi $\mathrm{O}-\mathrm{H}$ akan muncul serapan pada rannge area 3200-3650 cm-1 dengan intensitas melebar, gugus fungsi $\mathrm{C}-\mathrm{H}$ pada range area $690-900 \mathrm{~cm}-1$ dengan intensitas kuat, dan gugus fungsi $\mathrm{C}-\mathrm{O}$ pada range area $1050-1300 \mathrm{~cm}-1$ dengan intensitas kuat. Analisa selulosa mengunakan FTIR (Fourier Tramsform Infra Red) pulp alang-alang ini menunjukan adanya fungsi gugus $\mathrm{O}-\mathrm{H}$ pada titik $3409,93 \mathrm{~cm}-1$, gugus fungsi $\mathrm{C}-\mathrm{H}$ pada titik $899,27 \mathrm{~cm}-1$, dan gugus fungsi C-O pada titik $1254,52 \mathrm{~cm}-1$ dan $1161,8 \mathrm{~cm}-1$. Selain bilangan gelombang yang umum pada selulosa, terdapat serapan bilanagn gelombang 1512,19 $\mathrm{cm}-1$ yaitu vibrasi dari kerangka eter aromatik yang menandakan adanya lignin (Safrianti dkk, 2012). Sedangkan pada pulp alang -alng ini mmuncul pada titik $1512,81 \mathrm{~cm}-1$, keberadaan titik gugus fungsi tersebut menunjukan bahwa masih ada sisa lignin pada pulp alang-alang.

Berikut hasil analisa FTIR (Fourier Tramsform Infra Red) pulp alang-alng kondisi optimum :

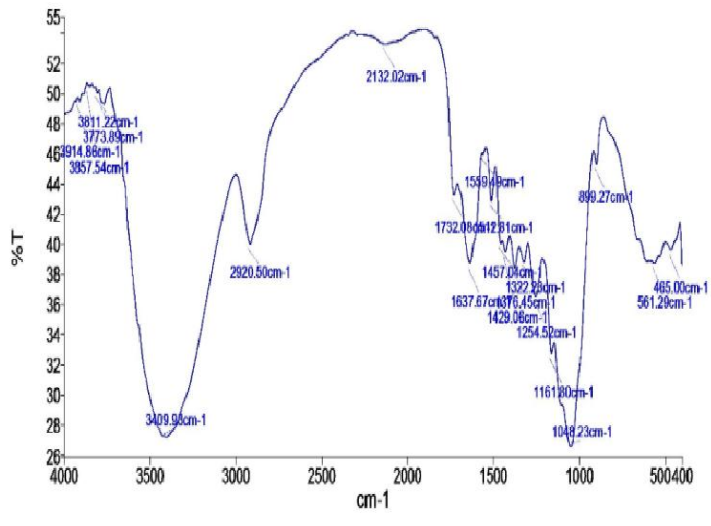

\section{Gambar 5. Hasil analisa FTIR Pulp alang- alang kondisi optimum.}

\section{KESIMPULAN}

Dari hasil penelitian dan pembahasan dapat disimpulkan bahwa :

1.) Kondisi optimum pemasakan pulp alangalang dengan proses alcell pada konsentrasi etanol $27,5 \%$, rasio berat volume $1: 10$, waktu pemasakan 60 menit, dan daya alat pada MAE (Microwave Assisted Extraction) sebesar 50\% dari daya maksimum 399 watt.

2.) Pada penelitian ini, dengan kondisi optimum, didapatkan ekstrak sebesar 8,05 gram dari berat awal 10 gram dan kadar bilangan kappa 4,5\% dari \% awal yakni $16,04 \%$. Jadi dapat disimpulkan bahwa kondisi optimum pada penelitian ini dapat mengurangi kadar bilangan kappa pada pulp alang-alang.

\section{DAFTAR PUSTAKA}

Badan Pusat Statiska dan Kehutanan Indonesia tahun (2012).

Coniwanti. (2009). Pengaruh Konsentrasi Larutan Etanol Temperatur dan Waktu Pemasakan pada Pembuatan Pulp Enceng Gondok Melalui Proses Organosolv. Jurnal Teknik Kimia, No.4, Vol. 16

Gautam. (2016). Effects of Ethanol Additional and Biological Pretreatment on Soda Pulping of Eulaliopsis binata. Jurnal of Biomaterials and Nanobiotechnology,2016,7,78-90

Hartati. (2010). Isolasi Alkaloid dari Tepung Gandum dengan Teknik Ekstraksi 
Berbantu Gelombang Mikro. Magister Teknik Kimia Universitas Diponegoro

Kartikasari. (2013). Potensi Alang-alang dalam produksi etanol menggunakan bakteri Zymomonas mobilis. Jurnal Sains dan Seni POMITS Vol.2 No.2, ITS.

Kholisoh. (2016). Aplikasi Organosolv Gelombang Mikro Pada Pembuatan Selulosa Mikrokristal dari Ampas Tebu, Fakultas Teknik Universitas Wahid Hasyim Semarang

Lamtiar. (2015). Isolasi Lignin dari jerami Padi dengan Metoda Klason, Universitas Riau

Mandall, V., Mohan, Y., Hemalatha, S. (2007).

Microwave Assisted Extraction-An Innovative and Promissing Extraction Tool for Medicinal Plant Research, Pharmacognosy Reviews, 1(1):18.

Miningsih. (2016).Adsorpsi Timbal (Pb) dalam Larutan Menggunakan Adsorben Radix Alang-alang Termodifikasi Asam Sitrat. Prosiding SNST ke-7.Fakultas Universitas Wahid Hasyim Semarang

Mutia, T., Susi S., Teddy K., Hendro R. (2014). Potensi Serat dan Pulp Bambu untuk Komposit Peredam Suara, Jurnal Selulosa, Vol. 4, No. 1.

Princilpe of Instrumetal analysis, Skoog, Holler, Nieman. (1998).

Rowe, R.C., sheskay, P.J., Owen, S.C. (2009).Handbook of Pharmaceutical Excipients. London : Pharmaceutical Press

Rozzaq,Raden M.N.A. (2013). Isolasi nanoselulosa dari biomassa batang pisang menggunakan cairan ionik cisoleil-imidazolinium asetat, Universitas Pendidikan Indonesia.

Sanjana.(2016).beny. http://www.crayonpedia.or $\mathrm{g} / \mathrm{mw} / 4$. Pengertian selulosa dan hemiselulosa. Diakses pada tanggal 7 oktober 2016 pukul 17.50 Wita

Wibisono I., Leonardo, H., Antaresti., dan Aylianawati. (2011). Pembuatan Pulp Dari Alang-Alang. Fakultas Teknik Jurusan Teknik Kimia Universitas Katolik Widyaa Mandala. Surabaya. 